\title{
Serratia glossinae sp. nov., isolated from the midgut of the tsetse fly Glossina palpalis gambiensis
}

Correspondence
A. Geiger
anne.geiger@mpl.ird.fr
A. Geiger, ${ }^{1}$ M.-L. Fardeau, ${ }^{2}$ E. Falsen, ${ }^{3}$ B. Ollivier ${ }^{2}$ and G. Cuny ${ }^{1}$

\author{
${ }^{1}$ UMR 177, IRD-CIRAD, CIRAD TA A-17/G, Campus International de Baillarguet, 34398 \\ Montpellier Cedex 5, France \\ ${ }^{2}$ Laboratoire de Microbiologie IRD, UMR 180, Universités de Provence et de la Méditerranée, ESIL, \\ case 925, 163 Avenue de Luminy, 13288 Marseille cedex 9, France \\ ${ }^{3}$ CCUG, Culture Collection, University of Göteborg, Guldhedsgatan 10, SE-413 46 Göteborg, \\ Sweden
}

We report the isolation of a novel bacterium, strain $\mathrm{C}^{\top}{ }^{\top}$, from the midgut of the tsetse fly Glossina palpalis gambiensis, one of the vector insects responsible for transmission of the trypanosomes that cause sleeping sickness in sub-Saharan African countries. Strain $C 1^{\top}$ is a motile, facultatively anaerobic, rod-like bacterium (0.8-1.0 $\mu \mathrm{m}$ in diameter; 2-6 $\mu \mathrm{m}$ long) that grows as single cells or in chains. Optimum growth occurred at $25-35{ }^{\circ} \mathrm{C}$, at $\mathrm{pH} 6.7-8.4$ and in medium containing 5-20 $\mathrm{g} \mathrm{NaCl} \mathrm{I}^{-1}$. The bacterium hydrolysed urea and used L-lysine, L-ornithine, citrate, pyruvate, D-glucose, D-mannitol, inositol, D-sorbitol, melibiose, amygdalin, L-arabinose, arbutin, aesculin, D-fructose, D-galactose, glycerol, maltose, D-mannose, raffinose, trehalose and D-xylose; it produced acetoin, reduced nitrate to nitrite and was positive for $\beta$-galactosidase and catalase. The DNA G + C content was 53.6 mol\%. It was related phylogenetically to members of the genus Serratia, family Enterobacteriaceae, the type strain of Serratia fonticola being its closest relative (99\% similarity between 16S rRNA gene sequences). However, DNA-DNA relatedness between strain $\mathrm{C}^{\top}$ and S. fonticola DSM $4576^{\top}$ was only $37.15 \%$. Therefore, on the basis of morphological, nutritional, physiological and fatty acid analysis and genetic criteria, strain $\mathrm{C} 1^{\top}$ is proposed to be assigned to a novel Serratia species, Serratia glossinae sp. nov. (type strain $\mathrm{C} 1^{\top}=\mathrm{DSM} 22080^{\top}=$ CCUG $57457^{\top}$ ).
Glossina species, the well-known tsetse flies, are the vectors of African trypanosomes, the causative agents of sleeping sickness in humans and nagana in animals. Despite progress in the understanding of the disease, there is no foreseeable progress towards producing mammalian vaccines or new effective and affordable drugs for chemotherapy, while drug resistance is increasing (De Koning, 2001; Mulugeta et al., 1997). Therefore, novel strategies must be investigated. Several approaches are possible, including genetic modification of the insect (Robinson et al., 2004) and also the use of the insect bacterial flora to control the insect host itself and/or the pathogen(s) it transmits (Beard et al., 1993; Durvasula et al., 1997). In this latter approach, bacteria that are highly adapted to the physiology of a particular insect are selected for their capacity to secrete naturally antiparasitic compounds in the insect gut, where both the bacteria and the parasite are harboured. The

The GenBank/EMBL/DDBJ accession number for the $16 \mathrm{~S}$ rRNA gene sequence of strain $\mathrm{C}^{\top}{ }^{\top}$ is $\mathrm{FJ} 790328$.

An electron micrograph of cells of strain $\mathrm{C} 1^{\top}$ and a comparison of its fatty acid profile with those of related Serratia type strains are available as supplementary material with the online version of this paper. isolation of the Gram-negative bacterium Serratia marcescens from the gut of Rhodnius prolixus (Azambuja et al., 2004) illustrates this possibility: this bacterium naturally produces prodigiosin, a pigment that is toxic for the parasite Trypanosoma cruzi (Azambuja et al., 2005). Bacteria genetically transformed to express compounds that can either block the transmission of pathogens (Durvasula et al., 1997; Favia et al., 2007) or harm the host insect directly (Chapco \& Kellin, 1994; Tang et al., 2004) can also be used.

Glossina species have been shown to harbour three different bacterial symbionts (Aksoy, 2000). One is a member of the Rickettsiaceae belonging to the genus Wolbachia (O'Neill et al., 1993). It infects a broad range of insect species, causing a variety of reproductive abnormalities. The other two are members of the family Enterobacteriaceae. The first, Wigglesworthia glossinidia (Aksoy, 2000), is the primary nutritional symbiont of the tsetse, synthesizing B vitamins (Akman et al., 2002), which are absent from the fly's diet of blood. The second, Sodalis glossinidius, is assumed to be involved in the vectorial competence of the fly (Welburn \& Maudlin, 1999; Geiger et al., 2007). Strategies that exploit 
these symbioses to control vector-borne disease have been suggested (Beard et al., 1993; Durvasula et al., 1997; Rio et al., 2004). It is possible that comparable strategies could be tested based on the use of other tsetse gut bacteria, if any. Thus, the major objective of our investigation was to isolate the micro-organisms of ecological significance within the tsetse gut microflora. Here, we report on a novel bacterial strain belonging to the genus Serratia, family Enterobacteriaceae, that was isolated from the midgut of insectary flies of the tsetse fly Glossina palpalis gambiensis.

G. palpalis gambiensis flies originated from individuals that had been field-collected in Burkina Faso (Africa). Pupae were collected from these flies. Following adult emergence, the population was maintained in a level 2 containment insectary at $23{ }^{\circ} \mathrm{C}$ and $80 \%$ relative humidity (Geiger et al., 2005 ) without any selection. Flies used in the present study for bacterial isolation were chosen randomly. Bacteria were isolated from 13 insectary-reared G. palpalis gambiensis flies. After surface sterilization with $1 \%$ sodium hypochlorite and $70 \%$ ethanol, the midgut of each fly was dissected and ground with a pestle.

Hungate tubes containing $2 \mathrm{ml}$ liquid Mitsuhashi and Maramorosch insect culture medium (MMI; PromoCell) (Mitsuhashi \& Maramorosch, 1964), which had previously been dispensed into the tubes under a $\mathrm{N}_{2} / \mathrm{CO}_{2}(80: 20$, v/v) gas stream and sterilized for $45 \mathrm{~min}$ at $110{ }^{\circ} \mathrm{C}$, were inoculated with (20\%) fetal bovine serum (FBS; Gibco). The ground midguts of each fly were then transferred individually to a tube. After homogenizing, a $250 \mu \mathrm{l}$ aliquot of the whole content was serially diluted in liquid medium to $10^{-10}$ to enrich only bacteria of ecological significance within the fly midgut: serial dilution in tubes was repeated at least twice. Tubes containing the highest dilutions $\left(10^{-9}\right.$, $10^{-10}$ ) were incubated without shaking under a microaerobic atmosphere providing $5 \% \mathrm{O}_{2}$ in the gas phase at $26-27{ }^{\circ} \mathrm{C}$ for $36-72 \mathrm{~h}$ prior to isolation of bacteria by repeated use of the Hungate roll tube technique (Hungate, 1969) on MMI solid medium (MMI, $20 \%$ FBS, $10 \%$ horse blood, gelified with $1.6 \%$ agar). MMI solid medium was prepared by autoclaving MMI with agar (Sigma-Aldrich). The culture medium was cooled to $50{ }^{\circ} \mathrm{C}$ in a water bath, and packed horse blood cells (Oxoid) and FBS were then added. The process of serial dilution in roll tubes was repeated at least twice in order to purify the cultures. Purity of the isolates was checked by microscopic observations.

Growth experiments were performed in duplicate, using Hungate tubes containing basal culture medium (MMI, $20 \%$ FBS).

Serratia fonticola DSM $4576^{\mathrm{T}}$ was obtained from the Deutsche Sammlung von Mikroorganismen und Zellkulturen (DSMZ, Braunschweig, Germany) and cultivated according to the procedures recommended by the DSMZ. Additional reference strains Serratia ficaria CCUG $14507^{\mathrm{T}}$, S. grimesii CCUG $15721^{\mathrm{T}}$, S. liquefaciens CCUG $9285^{\mathrm{T}}$, S. marcescens
CCUG $1647^{\mathrm{T}}$, S. plymuthica CCUG $14509^{\mathrm{T}}$, S. proteamaculans CCUG $14510^{\mathrm{T}}$, S. quinivorans CCUG $14187^{\mathrm{T}}$, S. ureilytica CCUG 50595 , S. entomophila CCUG $55496^{\mathrm{T}}$, S. odorifera CCUG $14508^{\mathrm{T}}$ and S. rubidaea CCUG $9286^{\mathrm{T}}$ were obtained from the CCUG and cultivated according to their recommended procedures. The morphological, nutritional, physiological and molecular characteristics of isolated strains were compared with those of the 12 Serratia type strains including S. fonticola DSM $4576^{\mathrm{T}}$.

The $\mathrm{pH}$, temperature and $\mathrm{NaCl}$ concentration for optimal growth of the type strains were determined using basal culture medium (MMI, $20 \%$ FBS). The initial $\mathrm{pH}$ was adjusted to 5.0. The $\mathrm{pH}$ range was obtained by injecting in Hungate tubes suitable aliquots of anaerobic stock solutions of $1 \mathrm{M} \mathrm{HCl}$ (acidic $\mathrm{pH}$ range) or $10 \% \mathrm{NaHCO}_{3}$ or $\mathrm{Na}_{2} \mathrm{CO}_{3}$ (basic $\mathrm{pH}$ range). Water baths ranging from 10 to $50{ }^{\circ} \mathrm{C}$ were used to test growth temperatures. To determine $\mathrm{NaCl}$ requirements, $\mathrm{NaCl}$ was weighed directly into the tubes before the medium was dispensed. Strain $\mathrm{Cl}^{\mathrm{T}}$ was subcultured under the same experimental conditions before growth rates were determined. The ability of the strains to metabolize various substrates was tested using API 20E and API 50CH profiles (API system; bioMérieux). Growth was monitored by measuring the $\mathrm{OD}_{580}$ and by microscopic observations. Morphological characteristics and the purity of cultures were observed with an Optiphot phase-contrast microscope (Nikon). Anaerobic growth was tested in Hungate tubes containing anaerobic medium without shaking. Aerobic growth was determined in Hungate tubes filled with air in the gas phase and incubated at $26-27{ }^{\circ} \mathrm{C}$ under 150 r.p.m. agitation. Growth was monitored by measuring the $\mathrm{OD}_{580}$ and by microscopic observations. All experiments were conducted in duplicate and repeated at least twice.

Fatty acid profiling was performed according to the MIDIMIS protocol (details are given at http://www.ccug.se/).

Genomic DNA of the strains was extracted using the Wizard genomic DNA purification kit (Promega). The 16S rRNA gene (positions 8 to 1492, Escherichia coli numbering) was amplified by PCR with the eubacteria-specific primers $8 \mathrm{~F}$ ( $5^{\prime}$-AGAGTTTGATCCTGGCTCAG-3') and 1492R (5'-GTCGTAACAAGGTAACCGTA-3'). The PCR product was purified using the Nucleo Spin Extract kit (Macherey Nagel) and cloned using the pGEM-T-easy cloning kit (Promega). A plasmid containing an insert of the correct length was purified with the Wizard Plus SV Minipreps DNA purification system (Promega) and sent for sequencing to GATC Biotech (Konstanz, Germany).

Prior to phylogenetic analysis, 1488 nucleotides of the $16 \mathrm{~S}$ rRNA gene sequences of the tsetse fly bacterial isolates and reference sequences available in GenBank (Benson et al., 1999) were aligned using the sequence aligner software from the Ribosomal Database Project II (Maidak et al., 2001) and the sequence alignment editor BioEdit version 5.0.9 (Hall, 1999). The resulting alignment was used to construct a maximum-likelihood tree (Yang, 1997) using 
the PHYML program (Guindon \& Gascuel, 2003). The robustness of the tree topology was tested by bootstrap analysis with 1000 resamplings (Felsenstein, 1985).

The $\mathrm{G}+\mathrm{C}$ content of strain $\mathrm{Cl}^{\mathrm{T}}$ was determined at the DSMZ using HPLC as described by Mesbah et al. (1989). DNA-DNA hybridization between $\mathrm{Cl}^{\mathrm{T}}$ and $S$. fonticola DSM $4576^{\mathrm{T}}$ was performed in duplicate at the DSMZ as described previously (Miranda-Tello et al., 2004).

The midguts of 13 G. palpalis gambiensis flies were dissected. Cultures from midgut bacteria were incubated at $26-27{ }^{\circ} \mathrm{C}$ for 3 days. White, circular colonies, $1 \mathrm{~mm}$ in diameter, appeared after 3 days of incubation at $26-27{ }^{\circ} \mathrm{C}$ in roll-tubes: 39 colonies were then cultured (three colonies per fly midgut). Only one type of cell was observed under the microscope. Individual bacteria were approximately $0.8-1 \mu \mathrm{m}$ in diameter and 2-6 $\mu \mathrm{m}$ long. They occurred mainly as single cells (Supplementary Fig. S1, available in IJSEM Online).

The 16S rRNA gene sequences of the 39 bacterial isolates from fly midguts were amplified and sequenced as described previously (Maidak et al., 2001; Miranda-Tello et al., 2003; Weisburg et al., 1991) and aligned using BioEdit. The 16S rRNA gene sequences of the 39 isolates were identical (represented by GenBank accession no. FJ790328), suggesting that they should be considered as members of the same species. These isolates showed less than $98 \% 16 \mathrm{~S}$ rRNA gene sequence similarity with the type strains of other Serratia species, except that of $S$. fonticola; S. fonticola DSM $4576^{\mathrm{T}}$ was the closest phylogenetic relative of the novel isolates ( $99 \%$ similarity) (Fig. 1). Strain $\mathrm{Cl}^{\mathrm{T}}$ was chosen for further characterization in comparison with S. fonticola DSM $4576^{\mathrm{T}}$. The G $+\mathrm{C}$ content of the DNA, as determined by HPLC, was $53.6 \mathrm{~mol} \%$, and was found to be identical to that of S. fonticola DSM $4576^{\mathrm{T}}$. However, DNA-DNA hybridization experiments revealed only

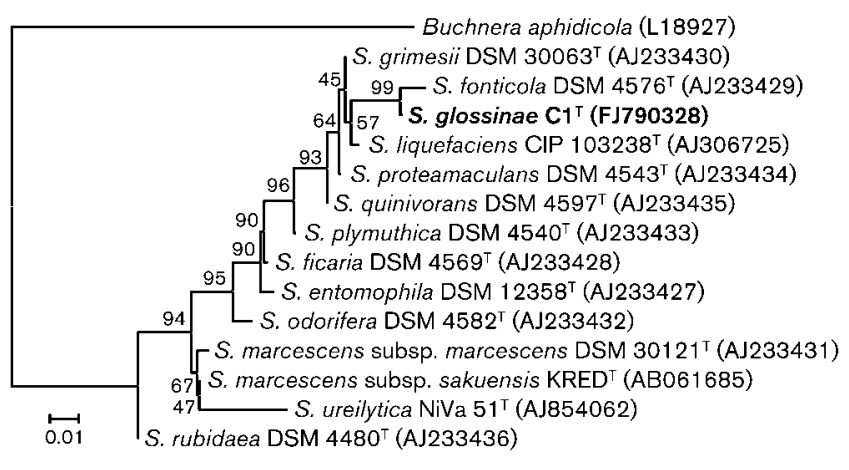

Fig. 1. Maximum-likelihood phylogenetic tree based on comparative analysis of $16 \mathrm{~S}$ rRNA gene sequence data indicating the position of strain $\mathrm{C}^{\top}{ }^{\top}$ among Serratia species. A sequence of Buchnera aphidicola was used as the outgroup and bootstrap values (percentages of 1000 tree replications) greater than $40 \%$ are displayed at nodes. Sequence accession numbers are shown in parentheses. Bar, 0.01 substitutions per nucleotide position.
$37.15 \%$ relatedness (individual values 37.0 and $37.3 \%$ ) between strain $\mathrm{C1}^{\mathrm{T}}$ and $S$. fonticola DSM $4576^{\mathrm{T}}$. Therefore, according to Wayne et al. (1987), strain $\mathrm{C}^{\mathrm{T}}$ cannot be affiliated with $S$. fonticola and should be considered as a member of a novel species of the genus Serratia.

The fatty acid profile of strain $\mathrm{Cl}^{\mathrm{T}}$ differed significantly from that of $S$. fonticola DSM $4576^{\mathrm{T}}$, notably in the content of $15: 0$ and $16: 1 \omega 7 c$ (Supplementary Table S1). However, the most marked difference between the fatty acid profiles of the tested strains concerned 17:0 cyclo, which was absent from strain $\mathrm{C1}^{\mathrm{T}}$ and made up $16.5 \%$ of the profile of S. fonticola DSM $4576^{\mathrm{T}}$, confirming that strain $\mathrm{Cl}^{\mathrm{T}}$ does not belong to $S$. fonticola.

Both strain $\mathrm{Cl}^{\mathrm{T}}$ and $S$. fonticola DSM $4576^{\mathrm{T}}$ were mesophilic (growing at $10-40{ }^{\circ} \mathrm{C}$ ) and were able to grow under aerobic and anaerobic conditions and in the same ranges of $\mathrm{pH}(4.8-8.9)$ and $\mathrm{NaCl}$ concentration (0$50 \mathrm{~g} \mathrm{l}^{-1}$ ). Table 1 shows biochemical characteristics of the type strains of Serratia species. Both $\mathrm{Cl}^{\mathrm{T}}$ and $S$. fonticola DSM $4576^{\mathrm{T}}$ were $\beta$-galactosidase-positive and used L-lysine, L-ornithine, citrate, inositol, D-sorbitol, melibiose, amygdalin, L-arabinose, arbutin, aesculin, D-galactose, glycerol, maltose, raffinose and D-xylose (Table 1), reduced nitrate to nitrite and were oxidase-negative. However, in contrast to S. fonticola DSM $4576^{\mathrm{T}}$, strain $\mathrm{C1}^{\mathrm{T}}$ hydrolysed urea and produced acetoin, used pyruvate, did not use L-rhamnose and was found to be catalase-positive. Based on phenotypic, genetic and phylogenetic characteristics, we therefore propose that strain $\mathrm{C1}^{\mathrm{T}}$, isolated from the tsetse fly $G$. palpalis gambiensis, should be assigned to a novel species of the genus Serratia, family Enterobacteriaceae, for which we propose the name Serratia glossinae sp. nov.

Members of the genus Serratia are ubiquitous, and 13 species are currently recognized; Serratia species have been isolated from water, soil, animals (including humans) and plant surfaces (Grimont \& Grimont, 1992). Some species are often associated with insects belonging to many orders (Grimont \& Grimont, 1978). Results suggest that Serratia species in general have metabolic features of ecological significance in interactions with insects, and these may be beneficial for or deleterious to the physiology of these invertebrates (Grimont et al., 1979; Oliver et al., 2006; Lamelas et al., 2008).

We are looking at other facets of the biology of the novel strain, including the role, if any, played by S. glossinae in the midgut of the tsetse fly. Another aspect that deserves to be investigated is the possibility of genetic engineering to produce strains that would express trypanolytic compounds. The selection and use of host-specific species to carry out such approaches should be favoured, since nonresident bacteria often cannot become established within a particular intestinal environment (Husseneder \& Grace, 2005; Husseneder et al., 2005; Thimm et al., 1998). Moreover, the use of transgenic bacteria that are closely associated with a single host species may reduce undesirable impacts on non-target insects. In research into 
Table 1. Biochemical characteristics of strain $\mathrm{C} 1^{\top}$ and Serratia type strains

Reference strains: 1, S. fonticola DSM $4576^{\mathrm{T}} ; 2$, S. ficaria CCUG $14507^{\mathrm{T}}$; 3, S. grimesii CCUG $15721^{\mathrm{T}} ; 4$, S. liquefaciens CCUG $9285^{\mathrm{T}} ; 5$, S. marcescens CCUG $1647^{\mathrm{T}} ; 6$, S. plymuthica CCUG $14509^{\mathrm{T}} ; 7, S$. proteamaculans CCUG $14510^{\mathrm{T}} ; 8$, S. quinivorans CCUG $14187^{\mathrm{T}} ; 9, \mathrm{~S}$. ureilytica CCUG $50595^{\mathrm{T}}$; 10 , S. entomophila CCUG $55496^{\mathrm{T}}$; $11, \mathrm{~S}$. odorifera CCUG $14508^{\mathrm{T}}$; 12 , S. rubidaea CCUG $9286^{\mathrm{T}}$. All strains were positive for utilization of D-glucose, D-mannitol, D-fructose, Dmannose and trehalose and were $\beta$-galactosidase-positive. All strains were negative for utilization of L-arginine, sodium thiosulfate, Ltryptophan, erythritol, glycogen and L-sorbose and were oxidasenegative. +, Positive; w, weakly positive; -, negative.

\begin{tabular}{|c|c|c|c|c|c|c|c|c|c|c|c|c|c|}
\hline Characteristic & $\mathrm{Cl}^{\mathrm{T}}$ & 1 & 2 & 3 & 4 & 5 & 6 & 7 & 8 & 9 & 10 & & 12 \\
\hline Urease & + & - & - & - & - & - & - & - & - & + & - & - & - \\
\hline Catalase & + & - & + & + & + & + & + & + & + & + & + & + & + \\
\hline $\begin{array}{l}\text { Indole } \\
\text { production }\end{array}$ & - & - & - & - & - & - & - & - & - & - & - & + & - \\
\hline $\begin{array}{l}\text { Acetoin } \\
\text { production }\end{array}$ & + & - & + & - & + & + & - & + & + & + & + & + & - \\
\hline \multicolumn{14}{|l|}{ Utilization of: } \\
\hline L-Lysine & + & + & - & + & + & + & - & + & + & + & - & + & - \\
\hline L-Ornithine & + & + & - & + & + & + & - & + & + & + & - & + & - \\
\hline $\begin{array}{l}\text { Trisodium } \\
\text { citrate }\end{array}$ & + & + & + & - & + & + & + & + & - & + & + & + & + \\
\hline Gelatin & - & - & + & - & - & + & - & - & + & + & + & + & + \\
\hline Pyruvate & + & - & + & - & + & + & - & + & + & + & + & + & - \\
\hline Inositol & + & + & - & + & + & + & - & + & + & + & + & + & + \\
\hline D-Sorbitol & + & + & + & + & + & + & + & - & - & + & - & + & - \\
\hline L-Rhamnose & - & + & + & - & - & - & - & - & + & - & - & + & - \\
\hline Sucrose & - & - & + & + & + & + & + & + & + & + & + & + & + \\
\hline Melibiose & + & + & + & + & + & + & + & - & + & - & - & & + \\
\hline Amygdalin & + & + & + & + & + & + & + & + & - & + & + & + & + \\
\hline L-Arabinose & + & + & + & + & + & + & + & + & + & - & - & + & + \\
\hline Arbutin & + & + & + & + & + & - & + & + & - & + & + & + & + \\
\hline Cellobiose & - & - & $\mathrm{w}$ & + & - & - & + & - & + & + & w & + & + \\
\hline Dextrin & $\mathrm{W}$ & - & - & - & - & - & - & $\mathrm{W}$ & + & + & - & $\mathrm{w}$ & - \\
\hline Aesculin & + & + & + & + & + & + & + & + & - & + & + & & + \\
\hline D-Galactose & + & + & + & + & + & - & + & + & + & + & + & + & + \\
\hline Glycerol & + & + & - & + & + & + & - & + & + & + & + & - & + \\
\hline Inulin & - & - & + & - & - & - & - & - & $\mathrm{w}$ & + & - & - & - \\
\hline Maltose & + & + & + & + & + & + & + & - & - & + & + & & + \\
\hline Melezitose & - & - & $\mathrm{w}$ & - & + & - & + & - & - & - & - & - & - \\
\hline Raffinose & + & + & - & + & $\mathrm{w}$ & - & + & - & + & - & - & & + \\
\hline Starch & - & - & - & + & - & - & - & - & - & - & - & - & - \\
\hline D-Xylose & + & + & + & + & + & - & + & + & + & - & - & & + \\
\hline
\end{tabular}

vector-parasite interactions and the control of sleeping sickness, our findings may be of particular interest. Finally, as discussed above, with the isolation of S. glossinae, we extend our knowledge of the ecological significance of members of the family Enterobacteriaceae within the midgut of insects. In addition, many questions have arisen from this research that deserve further attention from health scientists in efforts to control the spread of insectborne parasitic disease.

\section{Description of Serratia glossinae sp. nov.}

Serratia glossinae (glos.si'nae. N.L. gen. n. glossinae of Glossina, referring to the isolation of the type strain from the tsetse fly Glossina palpalis gambiensis).

Bacillus-like $(0.8-1.0 \mu \mathrm{m}$ in diameter; 2-6 $\mu \mathrm{m}$ long), motile, facultatively anaerobic bacterium that grows as single cells or in chains. Optimum growth occurs at 25$35{ }^{\circ} \mathrm{C}$, at $\mathrm{pH}$ 6.7-8.4 and in medium containing 5-20 g $\mathrm{NaCl} \mathrm{l}^{-1}$. Able to hydrolyse urea and to use L-lysine, Lornithine, citrate, pyruvate, D-glucose, D-mannitol, inositol, D-sorbitol, melibiose, amygdalin, L-arabinose, arbutin, aesculin, D-fructose, D-galactose, glycerol, maltose, Dmannose, raffinose, trehalose and D-xylose. Produces acetoin, reduces nitrate to nitrite and is positive for $\beta$ galactosidase and catalase. The DNA G+C content of the type strain is $53.6 \mathrm{~mol} \%$ (HPLC).

The type strain is strain $\mathrm{C}^{\mathrm{T}}\left(=\mathrm{DSM} 22080^{\mathrm{T}}=\mathrm{CCUG}\right.$ $57457^{\mathrm{T}}$ ), isolated from the midgut of the tsetse fly Glossina palpalis gambiensis.

\section{Acknowledgements}

We extend our thanks to Manon Joseph for technical assistance. We are grateful to Kent Molin for careful cellular fatty acid analysis. We also thank Dr Lionel Moulin for his help with the phylogeny software.

\section{References}

Akman, L., Yamashita, A., Watanabe, H., Oshima, K., Shiba, T., Hattori, M. \& Aksoy, S. (2002). Genome sequence of the endocellular obligate symbiont of tsetse flies, Wigglesworthia glossinidia. Nat Genet 32, 402-407.

Aksoy, S. (2000). Tsetse: a haven for microorganisms. Parasitol Today 16, 114-119.

Azambuja, P., Feder, D. \& Garcia, E. S. (2004). Isolation of Serratia marcescens in the midgut of Rhodnius prolixus: impact on the establishment of the parasite Trypanosoma cruzi in the vector. Exp Parasitol 107, 89-96.

Azambuja, P., Garcia, E. S. \& Ratcliffe, N. A. (2005). Gut microbiota and parasite transmission by insect vectors. Trends Parasitol 21, 568572.

Beard, C. B., O’Neill, S. L., Tesh, R. B., Richards, F. F. \& Aksoy, S. (1993). Modification of arthropod vector competence via symbiotic bacteria. Parasitol Today 9, 179-183.

Benson, D. A., Boguski, M. S., Lipman, D. J., Ostell, J., Ouellette, B. F., Rapp, B. A. \& Wheeler, D. L. (1999). GenBank. Nucleic Acids Res 27, 12-17.

Chapco, W. \& Kellin, R. A. (1994). Persistence of ingested bacteria in the grasshopper gut. J Invertebr Pathol 64, 149-150.

De Koning, H. P. (2001). Transporters in African trypanosomes: role in drug action and resistance. Int J Parasitol 31, 512-522.

Durvasula, R. V., Gumbs, A., Panackal, A., Kruglov, O., Aksoy, S., Merrifield, R. B., Richards, F. F. \& Beard, C. B. (1997). Prevention of insect-borne disease: an approach using transgenic symbiotic bacteria. Proc Natl Acad Sci U S A 94, 3274-3278.

Favia, G., Ricci, I., Damiani, C., Raddadi, N., Crotti, E., Marzorati, M., Rizzi, A., Urso, R., Brusetti, L. \& other authors (2007). Bacteria of the 
genus Asaia stably associate with Anopheles stephensi, an Asian malarial mosquito vector. Proc Natl Acad Sci U S A 104, 9047-9051.

Felsenstein, J. (1985). Confidence limits on phylogenies: an approach using the bootstrap. Evolution 39, 783-791.

Geiger, A., Ravel, S., Frutos, R. \& Cuny, G. (2005). Sodalis glossinidius (Enterobacteriaceae) and vectorial competence of Glossina palpalis gambiensis and Glossina morsitans morsitans for Trypanosoma congolense savannah type. Curr Microbiol 51, 35-40.

Geiger, A., Ravel, S., Mateille, T., Janelle, J., Patrel, D., Cuny, G. \& Frutos, R. (2007). Vector competence of Glossina palpalis gambiensis for Trypanosoma brucei s.l. and genetic diversity of the symbiont Sodalis glossinidius. Mol Biol Evol 24, 102-109.

Grimont, P. A. D. \& Grimont, F. (1978). The genus Serratia. Annu Rev Microbiol 32, 221-248.

Grimont, F. \& Grimont, P. A. D. (1992). The genus Serratia. In The Prokaryotes, 2nd edn, pp. 2822-2848. Edited by A. Balows, H. G. Trüper, M. Dworkin, W. Harder \& K. H. Schleifer. New York: Springer.

Grimont, P. A. D., Grimont, F. \& Starr, M. P. (1979). Serratia ficaria sp. nov., a bacterial species associated with Smyrna figs and the fig wasp Blastophaga psenes. Curr Microbiol 2, 277-282.

Guindon, S. \& Gascuel, O. (2003). A simple, fast, and accurate algorithm to estimate large phylogenies by maximum likelihood. Syst Biol 52, 696-704.

Hall, T. A. (1999). BioEdit: a user-friendly biological sequence alignment editor and analysis program for Windows 95/98/NT. Nucleic Acids Symp Ser 41, 95-98.

Hungate, R. E. (1969). A roll tube method for cultivation of strict anaerobes. Methods Microbiol 3B, 117-132.

Husseneder, C. \& Grace, J. K. (2005). Genetically engineered termite gut bacteria (Enterobacter cloacae) deliver and spread foreign genes in termite colonies. Appl Microbiol Biotechnol 68, 360-367.

Husseneder, C., Grace, J. K. \& Oishi, D. E. (2005). Use of genetically engineered Escherichia coli to monitor ingestion, loss, and transfer of bacteria in termites. Curr Microbiol 50, 119-123.

Lamelas, A., Pérez-Brocal, V., Gómez-Valero, L., Gosalbes, M. J., Moya, A. \& Latorre, A. (2008). Evolution of the secondary symbiont "Candidatus Serratia symbiotica" in aphid species of the subfamily Lachninae. Appl Environ Microbiol 74, 4236-4240.

Maidak, B. L., Cole, J. R., Lilburn, T. G., Parker, C. T., Jr, Saxman, P. R., Farris, R. J., Garrity, G. M., Olsen, G. J., Schmidt, T. M. \& Tiedje, J. M. (2001). The RDP-II (Ribosomal Database Project). Nucleic Acids Res 29, 173-174.

Mesbah, M., Premachandran, U. \& Whitman, W. B. (1989). Precise measurement of the $\mathrm{G}+\mathrm{C}$ content of deoxyribonucleic acid by highperformance liquid chromatography. Int J Syst Bacteriol 39, 159-167.
Miranda-Tello, E., Fardeau, M.-L., Cayol, J.-L., Thomas, P., Ostoa, P., Ramirez, F., Fernandez, L., Garcia, J.-L. \& Ollivier, B. (2003). Desulfovibrio capillatus sp. nov., a long-chained sulfate-reducing bacterium isolated from Gulf of Mexico oil well. Anaerobe 9, 97-103.

Miranda-Tello, E., Fardeau, M.-L., Thomas, P., Ramirez, F., Casalot, L., Cayol, J.-L., Garcia, J.-L. \& Ollivier, B. (2004). Petrotoga mexicana sp. nov., a novel thermophilic, anaerobic and xylanolytic bacterium isolated from an oil-producing well in the Gulf of Mexico. Int J Syst Evol Microbiol 54, 169-174.

Mitsuhashi, J. \& Maramorosch, K. (1964). Leafhopper tissue culture: embryonic, nymphal and imaginal tissues from aseptic insects. Contrib Boyce Thompson Inst 22, 435-460.

Mulugeta, W., Wilkes, J., Mulatu, W., Majiwa, P. A., Masake, R. \& Peregrine, A. S. (1997). Long-term occurrence of Trypanosoma congolense resistant to diminazene, isometamidium and homidium in cattle at Ghibe, Ethiopia. Acta Trop 64, 205-217.

Oliver, K. M., Moran, N. A. \& Hunter, M. S. (2006). Costs and benefits of a superinfection of facultative symbionts in aphids. Proc Biol Sci 273, 1273-1280.

O'Neill, S. L., Gooding, R. H. \& Aksoy, S. (1993). Phylogenetically distant symbiotic microorganisms reside in Glossina midgut and ovary tissues. Med Vet Entomol 7, 377-383.

Rio, R. V., Hu, Y. \& Aksoy, S. (2004). Strategies of the home-team: symbioses exploited for vector-borne disease control. Trends Microbiol 12, 325-336.

Robinson, A. S., Franz, G. \& Atkinson, P. W. (2004). Insect transgenesis and its potential role in agricultural and human health. Insect Biochem Mol Biol 34, 113-120.

Tang, C., Sun, F., Zhang, X., Zhao, T. \& Qi, J. (2004). Transgenic ice nucleation-active Enterobacter cloacae reduces cold hardiness of corn borer and cotton bollworm larvae. FEMS Microbiol Ecol 51, 79-86.

Thimm, T., Hoffman, A., Borkott, H., Munch, J. C. \& Tebbe, C. C. (1998). The gut of the soil microarthropod Folsomia candida (Collembola) is a frequently changeable but selective habitat and a vector for microorganisms. Appl Environ Microbiol 64, 2660-2669.

Wayne, L. G., Brenner, D. J., Colwell, R. R., Grimont, P. A. D., Kandler, O., Krichevsky, M. I., Moore, L. H., Moore, W. E. C., Murray, R. G. E. \& other authors (1987). International Committee on Systematic Bacteriology. Report of the ad hoc committee on reconciliation of approaches to bacterial systematics. Int J Syst Bacteriol 37, 463-464.

Weisburg, W. G., Barns, S. M., Pelletier, D. A. \& Lane, D. J. (1991). 16 S ribosomal DNA amplification for phylogenetic study. J Bacteriol 173, 697-703.

Welburn, S. C. \& Maudlin, I. (1999). Tsetse-trypanosome interactions: rites of passage. Parasitol Today 15, 399-403.

Yang, Z. (1997). PAML: a program package for phylogenetic analysis by maximum likelihood. Comput Appl Biosci 13, 555-556. 